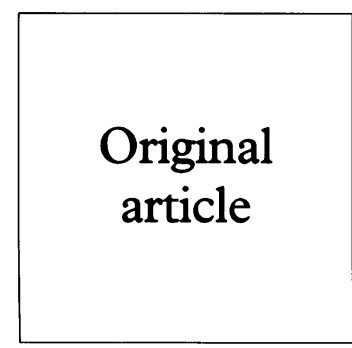

\title{
Epidemiology of genital Chlamydia trachomatis in England and Wales
}

\author{
I Simms, M Catchpole, R Brugha, P Rogers, H Mallinson, A Nicoll
}

Objective: To describe the recent epidemiology of genital Chlamydia trachomatis infection in England and Wales.

Design: Retrospective study of routinely available surveillance datasets and ad hoc prevalenc芦 studies.

Methods: Numbers of new cases of genital $C$ trachomatis infection, obtained from the Department of Health and Welsh Office, were combined with the estimated mid-year residenf population of England and Wales. Rates were analysed for trend over time using a log linear age period model in GLIM4. Ad hoc prevalence and case finding studies carried out over the past $2 \%$ years were critically assessed in terms of study design and testing methodologies.

Results: Attendance rates at genitourinary medicine (GUM) clinics were higher for women than men over the period 1989 to 1994 as were the number of laboratory reports. The highest rat of attendance (GUM clinic data) was for women aged 16 to 19 years. There was an overall $\operatorname{sig}_{\rightarrow}^{\oplus}$ nificant linear decrease in the attendance rates over time for both men $(p=0.0172)$ and women $(p=0.0000)$ between 1989 and 1994. There was considerable variation in the prevalence oif genital $C$ trachomatis infection detected within different clinical settings, together with a substan tial level of asymptomatic infection.

Conclusions: Genital $C$ trachomatis infection is broadly distributed throughout the sexually active population, with a substantial reservoir of asymptomatic infection among those generally perceived to be at low risk of a sexually transmitted infection. Young people, particularly wome aged 16 to 19 years, are at highest risk of genital $C$ trachomatis infection. This is of concern since younger women are more susceptible than older women to developing complications of chlamye dial infection, such as pelvic inflammatory disease. The broad distribution of infection across all sexually active health service attenders and the high level of asymptomatic infection suggest tha a new, screening based, approach to the control of genital $C$ trachomatis infection is required Recommendations are made as to the epidemiological research required to guide such work. (Genitourin Med 1997;73:122-126)

Keywords: Chlamydia trachomatis; epidemiology

\section{Introduction}

Genital Chlamydia trachomatis infection is the most common curable, bacterial sexually transmitted infection (STI) in England and Wales. ${ }^{12}$ As an STI, genital $C$ trachomatis infection has three important features; it is often subclinical, sequelae can be severe and, if untreated, infection may persist for more than a year. ${ }^{3}$ Health service attender surveys based on universal testing indicate that infection may be asymptomatic in up to $70 \%$ of infected women, ${ }^{45}$ and in $4 \%$ to $11 \%$ of infected men. ${ }^{67}$ In women, infection may lead to pelvic inflammatory disease (PID), ectopic pregnancy and infertility. These are costly to treat, have potentially serious lifetime consequences and make genital $C$ trachomatis infection the most economically important STI in industrialised countries after $\mathrm{HIV}$ infection. ${ }^{8}$ Paradoxically, treatment of initial infection is cheap and effective and single dose treatment is becoming available. ${ }^{9}$ The recent development of a variety of diagnostic tests, including enzyme immunoassay (EIA), direct fluorescent antigen detection (DFA) and DNA recombinant tests, ${ }^{10} 11$ has led to the rapid expansion of diagnostic facilities. ${ }^{12} 13$ Sensitive and specific urine based tests are now becoming available. ${ }^{14}$ These developments have cre- ated the opportunity for population base approaches to the control of genital $C \operatorname{tra}$ chomatis infection through screening those a risk. ${ }^{15}$ Such screening programmes have been shown to be effective in reducing the preva을 lence of both genital $C$ trachomatis infectio and pelvic inflammatory disease in the other countries. ${ }^{1617}$ The development of sucto approaches in England and Wales will need to be guided by knowledge of the epidemiologes of the infection in the population. Howevers published information describing its epidemin

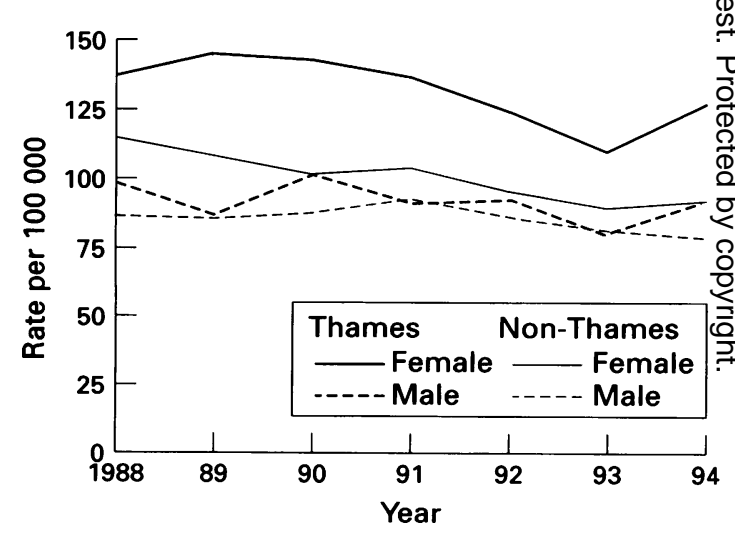

Figure 1 New cases of genital Chlamydia trachomatis seen in GUM clinics by area and sex, England and Wales. $1989^{\star}$ to 1994. (*Data for England only.) 
Figure 2 Laboratory reports of Chlamydia trachomatis-England and Wales 1981 to 1994.

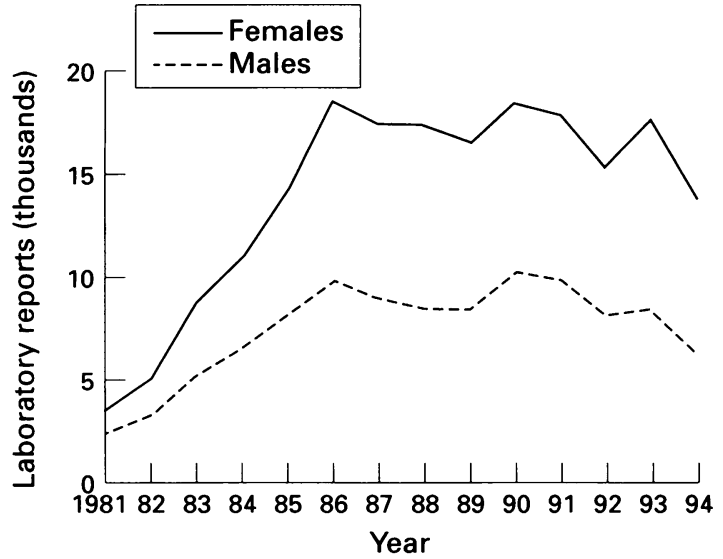

ology in England and Wales is limited. ${ }^{15}$ This paper summarises and discusses the most recently available epidemiological data, drawn from routine surveillance to the end of 1994, and published prevalence studies of genital $C$ trachomatis infection in England and Wales.

\section{Data sources}

Two sources of routine surveillance data were utilised. The first was quarterly returns from genitourinary medicine (GUM) clinics sent to

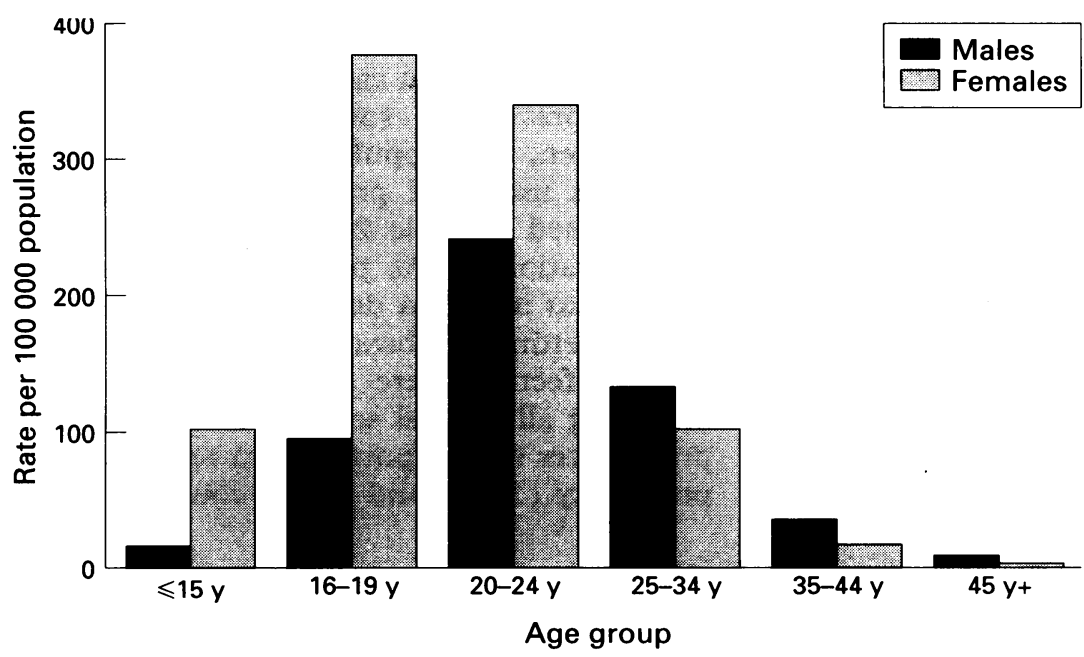

Figure 3 New cases of genital Chlamydia trachomatis infection seen in GUM clinics by age group and sex: 1994.

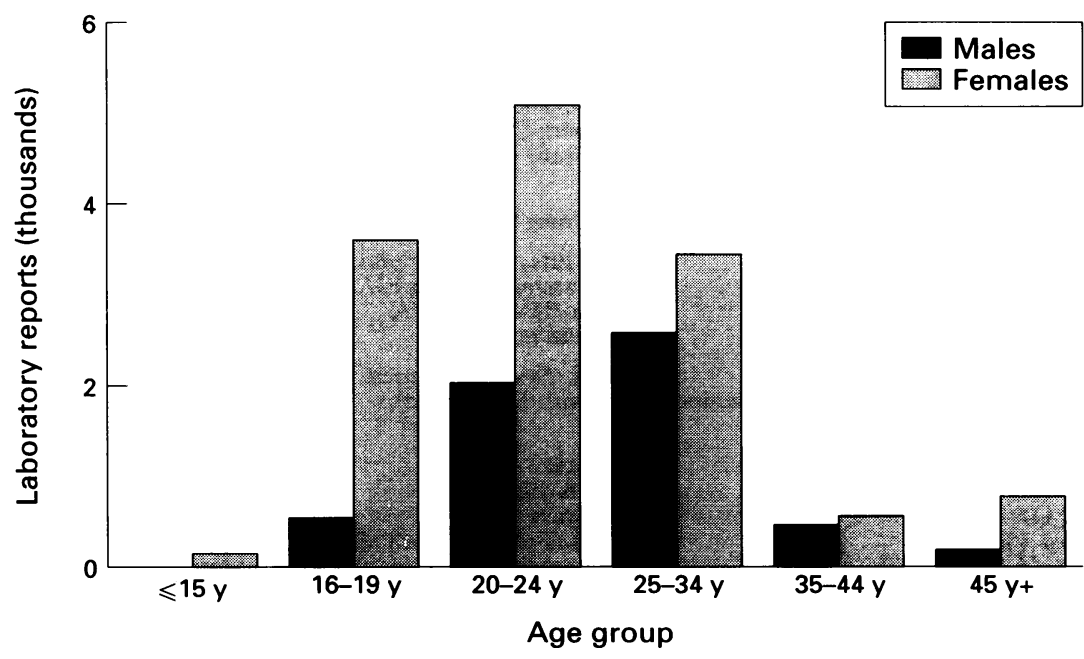

Figure 4 Laboratory reports of genital Chlamydia trachomatis by age group and sex: 1994. the Department of Health and the Welsh Office on form KC60. The data are available by sex, age group (under 16,16 to 19,20 to 24,25 to 34,35 to 44,45 and over) and regional health authority from 1989 (the first complete year that genital chlamydial infection was included as a separate diagnostic category) to 1994. Estimated rates of attendance for each age group were made by dividing the number of new cases in the calendar year by the estimated mid-year resident population of England and Wales aged between 15 and 59 for each age group. ${ }^{18}$ The denominator used for the under 16 group was taken as the population aged 15 since the number of cases decrease with decreasing age. This may, however, overestimate the rate in this age group.

A second routine surveillance dataset, reports of laboratory diagnosed genital $C$ trachomatis infection submitted to the Communicable Disease Surveillance Centre (CDSC) on a voluntary basis by microbiologists throughout England and Wales, was also used. Data on sex, age and laboratory name are submitted for each laboratory report. In addition, published reports from various ad hoc prevalence and case finding studies carried out in different populations over the past 20 years were reviewed. These were critically assessed for study design and laboratory testing methodologies.

\section{Methods}

The age specific attendance rates were plotted over time for each sex separately. To investigate the observed trends in more detail the GUM clinic data were analysed using a log linear age period model. ${ }^{19}$ The data were examined to see if there was evidence of an interaction between age group and year. Year and age group were included in the analysis as main effects and adjusted relative risks (RR) calculated using 1989 and the 16 to 19 age group as the baselines for year and age group, respectively. Year was subsequently analysed as a variable so that a polynomial could be fitted to the data for time trend analyses.

\section{Results}

Over the period 1989 to 1994 attendance rates at GUM clinics by women with diagnosed genital $C$ trachomatis infection were higher than those by men (fig 1), as were the number of laboratory reports of genital $C$ trachomatis infection made to CDSC between 1981 and 1994 (fig 2). For women, there was a higher attendance rate in the Thames regions than in the rest of England and Wales in every year between 1989 and 1994 (fig 1).

Attendance rates were highest in women aged 16 to 19 whereas, for men, they peaked in the 20 to 24 year age group (fig 3 ). In contrast, laboratory reports for 1994 peak in women aged 20 to 24 and in men aged 25 to 34 (fig 4).

The KC60 data for the period 1989 to 1994 were analysed separately for men and women. The data showed little evidence of interaction between age group and year (fig 5), so models 
Figure 5 New cases of Chlamydia trachomatis by year and age groupEngland and Wales 1989 to 1994.

infection

\begin{tabular}{|c|c|c|}
\hline \multirow[b]{2}{*}{ Year } & \multicolumn{2}{|c|}{ Adjusted RR ( $95 \%$ confidence limits) } \\
\hline & Males & Females \\
\hline $\begin{array}{l}1989 \\
1990 \\
1991 \\
1992 \\
1993 \\
1994\end{array}$ & $\begin{array}{l}1.00 \\
1.06(1.04-1.09) \\
1.08(1.05-1.10) \\
1.03(1.01-1.06) \\
0.97(0.95-0.99) \\
1.00(0.97-1.02)\end{array}$ & $\begin{array}{l}1.00 \\
0.97(0.95-0.99) \\
0.99(0.97-1.01) \\
0.93(0.91-0.95) \\
0.85(0.83-0.87) \\
0.96(0.94-0.98)\end{array}$ \\
\hline $\begin{array}{l}\text { Age group (years) } \\
\text { under } 16\end{array}$ & $0 \cdot 14(0 \cdot 12-0 \cdot 15)$ & $0 \cdot 26(0 \cdot 25-0 \cdot 28)$ \\
\hline $\begin{array}{l}16 \text { to } 19 \\
20 \text { to } 24 \\
25 \text { to } 34 \\
35 \text { to } 44 \\
45+\end{array}$ & $\begin{array}{l}1.00 \\
2.54(2.48-2.60) \\
1.38(1.35-1.41) \\
0.35(0.34-0.36) \\
0.090(0.086-0.094)\end{array}$ & $\begin{array}{l}1.00 \\
0.98(0.96-1.00) \\
0.300(0.296-0.306) \\
0.052(0.050-0.054) \\
0.012((0.011-0.012)\end{array}$ \\
\hline
\end{tabular}

including age group and year as main effects were fitted. RRs adjusted for the other variables are given in table 1 ; these quantify the results given in figure 5 . There were significant differences between age groups in both sexes (in both $\mathrm{p}=0.0000$ ). For men, the $95 \%$ confidence limit (CL) show the RR for each age group to be significantly different from each

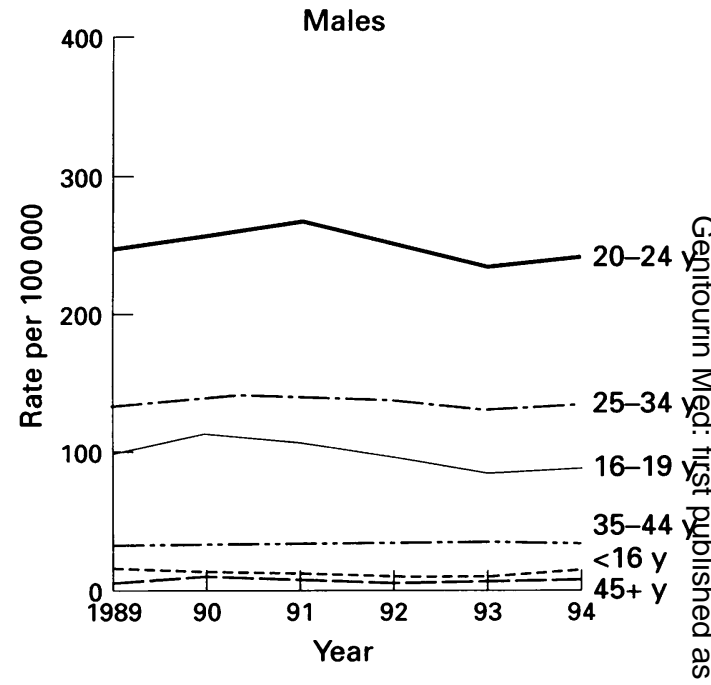
$R R$ between the 16 to 19 and 20 to 24 year ag groups for women. In men, the RR of the attendance rates for genital $C$ trachomatis infection rose to 1991, declined in 1992 and 1993 and subsequently rose in 1994 (fig 5). In $\overrightarrow{\text { b }}$ women, the RR was stable until 1991 and fell in 1992 and 1993 but subsequently rose in 1994. Overall the data showed a significan linear decrease over time for both sexes (men $p=0.0172$; women, $p=0.0000$ ). On average the rate of attendance decreased by $1 \%$ an $2 \%$ per year for men and women respectively:

The prevalence surveys that have beep undertaken, the populations studied, testing strategies used and prevalences detected aro summarised in table 2. There was consider able variation in the prevalence of genital $E$ trachomatis infection detected within differen clinical settings. Substantial levels of asympto matic infection were found among wome attending all clinical services. ${ }^{20-22}$ The highese prevalences were reported from termination of pregnancy (TOP) and GUM clinics, with the

Table 2 Published health service attender based surveys*

\begin{tabular}{|c|c|c|c|c|c|}
\hline Population & Location (year) & Sex & Prevalance (\%) (sample size) & Test used & Author (reference) \\
\hline Termination of pregnancy & $\begin{array}{l}\text { Swansea (1993) } \\
\text { London (1983) } \\
\text { Liverpool (1987) }\end{array}$ & $\begin{array}{l}\text { Female } \\
\text { Female } \\
\text { Female }\end{array}$ & $\begin{array}{c}9(32 / 400) \\
7 \cdot 8(7 / 89) \\
11(19 / 167)\end{array}$ & $\begin{array}{l}\text { EIA (Novo Norsisk) } \\
\text { Culture } \\
\text { Culture }\end{array}$ & $\begin{array}{l}\text { Blackwell (36) } \\
\text { Ridgway (24) } \\
\text { Duthie (25) }\end{array}$ \\
\hline Gynaecology clinic & $\begin{array}{l}\text { London (1989) } \\
\text { Kent (1993) }\end{array}$ & $\begin{array}{l}\text { Female } \\
\text { Female }\end{array}$ & $\begin{array}{l}3 \cdot 6(45 / 1267) \\
6 \cdot 3(102 / 1611)\end{array}$ & $\begin{array}{l}\text { Culture } \\
\text { EIA (IDEIA) }\end{array}$ & $\begin{array}{l}\text { Fish (37) } \\
\text { Edet (26) }\end{array}$ \\
\hline General practice & $\begin{array}{l}\text { London (1987) } \\
\text { Sheffield (1993) }\end{array}$ & $\begin{array}{l}\text { Female } \\
\text { Male }\end{array}$ & $\begin{array}{c}10 \cdot 7(18 / 169) \\
6(18 / 293)\end{array}$ & $\begin{array}{l}\text { EIA (IDEIA), compared } \\
\text { with culture } \\
\text { DFA (MicroTrak), culture } \\
\text { EIA (Dako), confirmed } \\
\text { with DFA (Syva) }\end{array}$ & $\begin{array}{l}\text { Smith (21) } \\
\text { Longhurst (38) } \\
\text { Kudesia (29) }\end{array}$ \\
\hline $\begin{array}{l}\text { (including practice } \\
\text { antenatal clinic) }\end{array}$ & London (1983) & Female & $8(19 / 248)$ & Culture & Southgate (39) \\
\hline Colposcopy & Glasgow (1991) & Female & $6(6 / 101)$ & Culture (Syva MicroTrak) & Smith (21) \\
\hline Family planning & $\begin{array}{l}\text { Manchester (1989) } \\
\text { Wirral (1990) }\end{array}$ & $\begin{array}{l}\text { Female } \\
\text { Female }\end{array}$ & $\begin{array}{l}7 \cdot 3(33 / 452) \\
9 \cdot 1(23 / 252)\end{array}$ & $\begin{array}{l}\text { Culture, some samples } \\
\text { examined using EIA test } \\
\text { EIA (IDEIA), DFA } \\
\text { and culture }\end{array}$ & $\begin{array}{l}\text { Macaulay (27) } \\
\text { Hopwood (28) }\end{array}$ \\
\hline $\begin{array}{l}\text { Community clinic (cervical } \\
\text { smear) }\end{array}$ & Liverpool (1995) & Female & $\begin{array}{l}7 \cdot 1(7 / 99) \text { referred to GUM } \\
7 \cdot 1(21 / 295) \text { symptoms of infection } \\
51 \cdot 5(33 / 64) \text { asymptomatic }\end{array}$ & $\begin{array}{l}\text { EIA (Syva) confirmed } \\
\text { with DFA (Syva) }\end{array}$ & Hopwood (22) \\
\hline Genitourinary medicine & $\begin{array}{l}\text { London (1978) } \\
\text { London (1994) } \\
\text { Bristol (1980) } \\
\text { Birmingham (1989) } \\
\text { Bristol (1990) } \\
\text { London (1995) }\end{array}$ & $\begin{array}{l}\text { Female } \\
\text { Female } \\
\text { Female } \\
\text { Male } \\
\text { Male }\end{array}$ & $\begin{array}{l}20 \cdot 4(58 / 284) \\
29(38 / 182) \\
19(154 / 796) \\
16 \cdot 1(68 / 422) \\
16 \cdot 7(103 / 615) \\
8 \cdot 6(31 / 356)\end{array}$ & $\begin{array}{l}\text { Culture } \\
\text { DFA (Syva) } \\
\text { Culture } \\
\text { EIA (Boots Celltech IDEIA), } \\
\quad \text { compared with culture } \\
\text { EIA, (IDEIA), confirmed } \\
\quad \text { with DFA (Syva) } \\
\text { Culture }\end{array}$ & $\begin{array}{l}\text { Oriel (40) } \\
\text { Hay (41) } \\
\text { Richmond (42) } \\
\text { Matthews (43) } \\
\text { Paul (20) } \\
\text { Zelin (44) }\end{array}$ \\
\hline
\end{tabular}


lower prevalences seen in general practice and family planning clinics. In those studies that reported both genital Neisseria gonorrhoeae and $C$ trachomatis infection, the prevalence of genital $C$ trachomatis infection was, with one exception, ${ }^{23}$ substantially higher than that of gonorrhoea. ${ }^{212425}$ Younger age category, a new sexual partner in the last two months, use of non-barrier contraceptives and low socioeconomic status have been associated with genital chlamydial infection among female clinic attenders. ${ }^{21226-28}$ Younger age category is the only factor that has been associated with infection in male clinics attenders. ${ }^{29}$

\section{Discussion}

Surveillance data and epidemiological studies provide an important insight into the epidemiology of genital $C$ trachomatis infection in England and Wales. Comparisons between the surveillance data sources are difficult to make since the laboratory data are derived from a variety of clinical settings whereas the KC60 dataset only reflects attendances at GUM clinics. This could account for the differences in the age group and trend over time data between these datasets. Data interpretation is further complicated by the large pool of symptomatic and asymptomatic infection that is either seen in clinical settings other than GUM clinics or that remains undiagnosed. Population estimates, based on prevalence studies in population groups, suggest that only $10 \%$ of prevalent cases are identified within GUM clinics, ${ }^{30}$ and that the KC60 dataset represents only a small proportion of prevalent infections. There are a number of problems associated with the interpretation of data derived from prevalence studies. The studies undertaken to date have generally been based on small numbers, confined to healthcare attender populations and have included a wide range of sampling and testing methodologies. The wide range of testing methodologies represents a particular problem because the sensitivity and specificity varies between testing strategies and over time. ${ }^{31}$ This will have influenced not only the number of positive cases detected but also the number of false positives detected. These limitations indicate that the detected prevalences are not absolute levels and consequently the interpretation of risk factor data is difficult, as are comparisons between studies and extrapolation of findings to the wider population.

Infection is broadly distributed throughout the sexually active female population, with a substantial reservoir of asymptomatic infection among those generally perceived to be at low risk of an STI, such as general practice attenders. Young people, particularly women aged 16 to 20 years, are at highest risk of chlamydial infection. However, the surveillance data are likely to underestimate the prevalence of infection in this age group since younger sexually active people are less likely to be seen in GUM clinics. ${ }^{32}$ This is of concern since younger women may be more susceptible than older women to developing complications of chlamydial infection, such as PID. ${ }^{33-35}$
The available data provide an incomplete epidemiological picture of what is being increasingly recognised as a disease of major public health importance. Surveillance has been mainly focused on high risk populations (that is, GUM clinic attenders) whereas the majority of genital $C$ trachomatis infections are likely to be asymptomatic and broadly distributed throughout the general population. Since current evidence suggests that transmission by people with asymptomatic infection in lower behavioural risk groups is maintaining the epidemic, ${ }^{4}$ a new approach to the control of genital $C$ trachomatis infection is required. However, presently there is insufficient knowledge of the epidemiology of genital $C$ trachomatis infection in England and Wales on which to base cost effective intervention strategies. Screening based studies in population groups are essential if our understanding of the epidemiology of genital $C$ trachomatis infection, particularly asymptomatic infection, is to be improved. Representative cross sectional studies using validated and standardised diagnostic tests, sampling accessible population groups, such as TOP, GUM, general practice, family planning and gynaecology clinics, are needed. These will provide accurate estimates of the prevalence of genital $C$ trachomatis infection and identify risk factors for infection which would be essential to the planning of future chlamydial control and prevention programmes.

This work was supported by a Department of Health research grant. We also thank Mr L Lanucuki (Department of Health), Mrs D Leigh (Welsh Office), Dr J Hopwood (Liverpool Health
Authority) and Mr P Crow (OPSC) for providing data, Dr A Authority) and Mr P Crow (OPSC) for providing data, Dr A
Renton (Academic Department of Public Health, St Mary's Hospital) and Dr O Caul (Bristol PHL) for their helpful comments on the manuscript, Tony Swan and Daniela DeAngelis (PHLS Statistics Unit) for statistical advice and Lisa Forsyth and Penny Cooper for preparation of illustrations.

1 Sexually transmitted diseases quarterly report: genital infection with Chlamydia trachomatis in England and Wales. Communicable Disease Report Weekly 1996;6: 190-1.

2 Sexually transmitted diseases quarterly report: gonorrhoea in England and Wales. Communicable Disease Report Weekly 1996;6:110-1.

3 McCormack WM, Alpert S, McComb DE, Nichols RL, Semine DZ, Zinner SH. Fifteen-month follow-up study of women infected with Chlamydia trachomatis. $N$ Engl $\mathcal{f}$ Med 1979;300:123-5.

4 Zimmerman HL, Potterat JJ, Dukes RL, Muth JB, Zimmerman HP, Fogle JS, et al. Epidemiologic differences between chlamydia and gonorrhea. Am $¥$ Public Health 1990;80:1338-42.

5 Lycke E, Löwhagen GB, Hallhagen G, Johannisson G, Ramstedt $\mathrm{K}$. The risk of transmission of genital Chlamydia trachomatis infection is less than that of genital Neisseria gonorrhoeae infection. Sex Transm Dis 1980;7: 6-10.

6 Karam GH, Martin DH, Flotte TR, Bonnarens FO, Joseph JR, Mroczkowski TF, et al. Asymptomatic Chlamydia trachomatis infections among sexually active men. $\mathcal{F}$ Infect Dis 1995;154:900-3.

7 Crowley T, Milne D, Arumainayagam JT, Paul ID, Caul EO. The laboratory diagnosis of male Chlamydia traEO. The laboratory diagnosis of male Chlamydia tra-
chomatis infections-a time for change? $\mathcal{f}$ Infect 1995;

8 World Bank. World development report 1993. Investing in health. Oxford: Oxford University Press, 1993.

9 Thorpe EM, Stamm WE, Hook EW, Gall SA, Jones RB, Whitworth G, et al. Chlamydial cervicitis and urethritis: single dose treatment compared with doxycycline for seven days in community based practices. Genitourin Med 1996;72:93-7.

10 Taylor-Robinson D, Thomas BJ. Laboratory techniques for the diagnosis of chlamydial infections. Genitourin Med 1991;67:256-66.

11 Jones RB. New treatments for Chlamydia trachomatis. Am $\mathfrak{f}$ Obstet Gynecol 1991;164:1789-93.

12 British Co-operative Clinical Group. Survey of diagnostic facilities for Chlamydia trachomatis and herpes simplex virus, 1984. Genitourin Med 1987;63:26-7.

13 Radcliffe KW, Rowen D, Mercey DE, Bingham JS. Survey 
of the management of Chlamydia trachomatis infection of the cervix. Genitourin Med 1991;67:41-3.

14 Taylor-Robinson D. Tests for infections with Chlamydia trachomatis. Int $\mathcal{F}$ STD AIDS 1996;7:19-26.

15 Taylor-Robinson D. Chlamydia trachomatis and sexually transmitted disease. What do we know and what shall we do? BMF 1994;308:150-1.

16 Herrmann $\mathrm{BF}$, Johansson $\mathrm{AB}$, Mårdh $\mathrm{P}$. A retrospective study of efforts to diagnose infections by Chlamydia trachomatis in a Swedish county. Sex Transm Dis 1991;18: 233-7.

17 Scholes D, Stergachis A, Heidrich FE, Andrilla H, Holmes $\mathrm{KK}$, Stamm WE. Prevention of pelvic inflammatory disease by screening for cervical chlamydial infection. $N$ Engl F Med 1996;334:1362-6.

18 Office of Population Censuses and Surveys. Revised mid1994 population estimates for local and health authorities in England and Wales, Series PP1. London: HMSO, 1996.

19 Clayton D, Schifflers E. Models for temporal variation in cancer rates I: age-period and age-cohort models. Stat Med 1987;6:449-67.

20 Paul ID, Crowley T, Milne JD, Caul EO. A comparison of urine and urethral swabbing for the diagnosis of $C$ trachomatis infection in males. Serodiagn Immunother Infect Dis 1995;4:473-80.

21 Smith JR, Murdoch J, Carrington D, Frew CE, Dougall AJ MacKinnon $\mathrm{H}$, et al. Prevalence of Chlamydia trachomatis infection in women having cervical smear tests. $B M \mathcal{F}$ 1991;302:82-4.

22 Hopwood J, Mallinson $\mathrm{H}$. Chlamydia testing in community clinics - a focus for accurate sexual health care. Br 7 Fam Planning 1995;21:87-90.

23 Harry TC, Saravanamuttu KM, Rashid S, Shrestha TL. Audit evaluating the value of routine screening of Chlamydia trachomatis urethral infections in men. Int $\mathcal{f}$ STD AIDS 1994;5:374-5.

24 Ridgway GL, Mumtaz G, Stephens RA, Oriel JD. Therapeutic abortion and chlamydial infection. $B M^{\mathcal{F}}$ 1983;286:1478-9.

25 Duthie SJ, Hobson D, Tait IA, Pratt BC, Lowe N, Sequeira PJL, et al. Morbidity after termination of pregnancy in first trimester. Genitourin Med 1987;63:182-7.

26 Edet EE. The prevalence of Chlamydia trachomatis infection among gynaecological patients. Br f Clin Pract 1993;47: 21-2.

27 Macaulay ME, Riordan T, James JM, Leventhall PA, Morris EM, Neal BR, et al. A prospective study of genital infections in a family-planning clinic. Epidemiol Infect 1990;104:55-61.

28 Hopwood J, Mallinson H, Agnew E. Chlamydia screening - should it be offered as a routine? $\mathrm{Br} \mathcal{F}$ Fam Planning 1990;16:59-67.

29 Kudesia G, Zadik PM, Ripley M. Chlamydia trachomatis infection in males attending general practitioners. Genitourin Med 1993;70:356.

30 Renton A, Taylor-Robinson D. The need for an assessment of health technology for screening for Chlamydia tra- chomatis in the population. National Health Service Executive.

31 Schachter J. Evolution of diagnostic tests for Chlamydia trachomatis infections. Bologna: Societa Editrice Esculapio; Societa Editrice Esculapio; p243. Proceedings of the Third Meeting of the European Society for Chlamydia Research, Vienna, 1996.

32 Whatley J, Thin N, Reynolds B, Blackwell A. Problems of adolescent sexuality. $\mathcal{F} R$ Soc Med 1989;82:732-4.

33 Weström L, Mårdh P-A. Acute pelvic inflammatory disease ${ }^{\mathbb{D}}$ (PID). In: Holmes KK, Mårdh P-A, Sparling PF, Wiesner PJ, eds. Sexually Transmitted Diseases. New York:O McGraw-Hill Information Services Company, 1990.

34 Cates JRW, Rolfs Jr RT, Aral SO. Sexually transmitted diseases, pelvic inflammatory disease, and infertility: an

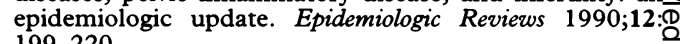
199-220.

35 Wasserheit $\mathrm{JN}$. Effect of changes in human ecology and behaviour on patterns of sexually transmitted diseases, including human immunodeficiency virus infection. Proeo Natl Acad Sci USA 1994;91:2430-5.

36 Blackwell AL, Thomas PD, Wareham K, Emery SJ. Health gains from screening for infection of the lower genitals tract in women attending for termination of pregnancy. Lancet 1993;342:206-10.

37 Fish ANJ, Fairweather DVI, Oriel JD, Ridgway GL Chlamydia trachomatis infection in a gynaecology clinic population: identification of high-risk groups and theo value of contact tracing. Eur $\mathcal{F}$ Obstet Gynecol Reprod Biol 1989;31:67-74.

38 Longhurst $\mathrm{HJ}$, Flower N, Thomas BJ, Munday PE, Eldero A, Constantinidou M, et al. A simple method for theen detection of Chlamydia trachomatis infections in generaf practice. IR Col Gen Pract 1987;37:255-6.

39 Southgate L, Treharne JD, Forsey T. Chlamydia trachomatis and Neisseria gonorrhoeae infections in women attending inner city general practices. BMF 1983;287:879-81.

40 Oriel JD, Barlow AL, Barlow D, Thomas BJ, Nayyar K, N Reeve P. Infection of the uterine cervix with Chlamydia trachomatis. 7 Infect Dis 1978;137:443-51.

41 Hay PE, Thomas BJ, Horner PJ, MacLeod E, Renton AM, Taylor-Robinson D. Chlamydia trachomatis in women the more you look, the more you find. Genitourin Med 1994;70:97-100.

42 Richmond SJ, Paul ID, Taylor PK. Value and feasibilityco of screening women attending STD clinics for cervical chlamydial infections. $\mathrm{Br} \mathcal{F}$ Venereal Dis $1980 ; 56$ : 92-5.

43 Matthews RS, Wise R. Non-invasive sampling method for detecting Chlamydia trachomatis. Lancet 1989;i:96.

44 Zelin JM, Robinson AJ, Ridgway GL, Allason-Jones E, Williams P. Chlamydial urethritis in heterosexual men attending a genitourinary medicine clinic: prevalence, $\Phi$ (nt $\exists S T D$ symptoms, condom usage and partner change. Int $f S T D$

45 Wood PL, Hobson D, Rees E. Genital infections with Chlamydia trachomatis in women attending an antenatal clinic. Br $\mathcal{F}$ Obstet Gynaecol 1984;91:1171-6. 